\author{
ZBIGNIEW KWIECIŃSKI \\ Uniwersytet Mikołaja Kopernika w Toruniu \\ BOGUSŁAW ŚLIWERSKI \\ Akademia Pedagogiki Specjalnej \\ im. Marii Grzegorzewskiej w Warszawie
}

\title{
NAGRODA NAUKOWA IM. WŁADYSŁAWA SPASOWSKIEGO Z PEDAGOGIKI W 2018 ROKU
}

Nagroda Naukowa im. Władysława Spasowskiego z pedagogiki w 2018 r. została przyznana przez Wydział I Nauk Humanistycznych i Społecznych PAN panu dr. hab. Michałowi Klichowskiemu z Wydziału Studiów Edukacyjnych UAM w Poznaniu za znakomitą rozprawę naukową pt. Learning in CyberParks. $A$ theoretical and empirical study (Wydawnictwo Naukowe Uniwersytetu im. Adama Mickiewicza w Poznaniu, Poznań 2017). Uroczystość wręczenia odbyła się 13 grudnia 2018 r. w PAN w Warszawie.

Nagrodzona monografia jest interdyscyplinarną, teoretyczno-empiryczną analizą problemu uczenia się w CyberParkach. Jej autor podjął się omówienia najbardziej aktualnego zjawiska społecznego na świecie. Jego książka nie jest jedynie rekonstrukcją teorii czy socjopedagogicznych studiów w literaturze światowej, ale zawiera także wyniki badań empirycznych. Autor opisał przebieg i wyniki dwóch przeprowadzonych przez siebie eksperymentów, w których zweryfikował koncepcję uczenia się w CyberParkach. W badaniach tych wykorzystał dwa klasyczne paradygmaty badania procesu uczenia się: Sternberg task i two-back task. Podczas eksperymentów, które realizował w naturalnych warunkach, dokonał analizy nie tylko behawioralnych efektów uczenia się, ale także tego, co dzieje się w mózgu w trakcie procesu uczenia się, wyko rzystując mobilny elektroencefalograf (zakupiony w ramach dofinansowania MNiSW). Taka organizacja badań nie tylko spełniała kryteria współczesnej nauki, ale była także innowacyjna oraz unikatowa w skali światowej. Monografia została napisana w języku angielskim, a wydana przez znaczącą w środowi- 
sku akademickiej pedagogiki w kraju oficynę uniwersytecką UAM. Laureat Nagrody jest młodym uczonym (ur. 16.03.1987 r. w Poznaniu), znakomicie osadzonym w sieci międzynarodowych badaczy najnowocześniejszych teorii i modeli uczenia się wspomaganego technologicznie, takich jak smart learning czy smart education. 